\title{
Bacteriophages as an Alternative Strategy for Fighting Biofilm Development
}

\author{
SYLWIA PARASION ${ }^{1 *}$, MAGDALENA KWIATEK $^{1}$, ROMUALD GRYKO${ }^{1}$, LIDIA MIZAK $^{1}$ \\ and ANNA MALM ${ }^{2}$ \\ ${ }^{1}$ Military Institute of Hygiene and Epidemiology, Biological Threat Identification \\ and Countermeasure Centre, Puławy, Poland \\ ${ }^{2}$ Medical University of Lublin, Department of Pharmaceutical Microbiology, Lublin, Poland
}

Submitted 2 February 2013, revised 14 July 2013, accepted 6 February 2014

\begin{abstract}
The ability of microbes to form biofilms is an important element of their pathogenicity, and biofilm formation is a serious challenge for today's medicine. Fighting the clinical complications associated with biofilm formation is very difficult and linked to a high risk of failure, especially in a time of increasing bacterial resistance to antibiotics. Bacterial species most commonly isolated from biofilms include coagulase-negative staphylococci, Staphylococcus aureus, Enterococcus faecalis, Enterococcus faecium, Escherichia coli, Proteus mirabilis, Klebsiella pneumoniae, Pseudomonas aeruginosa and Acinetobacter spp. The frequent failure of antibiotic therapy led researchers to look for alternative methods and experiment with the use of antibacterial factors with a mechanism of action different from that of antibiotics. Experimental studies with bacteriophages and mixtures thereof, expressing lytic properties against numerous biofilm-forming bacterial species showed that bacteriophages may both prevent biofilm formation and contribute to eradication of biofilm bacteria. A specific role is played here by phage depolymerases, which facilitate the degradation of extracellular polymeric substances (EPS) and thus the permeation of bacteriophages into deeper biofilm layers and lysis of the susceptible bacterial cells. Much hope is placed in genetic modifications of bacteriophages that would allow the equipping bacteriophages with the function of depolymerase synthesis. The use of phage cocktails prevents the development of phage-resistant bacteria.
\end{abstract}

Ke y words: biofilm, bacteriophage, anti-biofilm activity

\section{Introduction}

Biofilms are complex microbial aggregates located at interphases and forming dynamic structures characterized by diverse metabolic processes and interactions between individual components. The ability of biofilm formation is an important factor promoting microbial survival, as well as an important element of microbial pathogenicity. Biofilms are responsible mostly for infections associated with the use of biomaterials, as well as for many chronic diseases not responding to standard antibiotic treatment. For many years, studies were conducted to develop efficient methods of biofilm elimination and prevention. One of the methods involves the use of bacteriophages, i.e. bacterial viruses that are their natural enemies. Phage therapy has been used to fight bacterial infections in humans, animals and plants. The therapeutic effects of bacteriophages have been confirmed in many studies and are undoubtedly worthy of more attention as a research subject.

\section{Biofilm as a challenge for today's medicine}

The definition of biofilm has changed significantly from the first description of the phenomenon nearly 70 years ago (Zobell, 1943). Currently, biofilm is defined as a multicellular population of prokaryotic and/or eukaryotic cells. These cells are characterized by their spatial order, formation of extracellular polymeric substances (EPS) and increased tolerance to antimicrobial agents (Costerton, 2007; Trafny, 2008). In nature, biofilms may be formed by numerous species of bacteria, fungi, protozoans and algae. However, most attention is paid to bacteria, as it is estimated that $99 \%$ of microbes present in ecosystems may grow as metabolically integrated populations, i.e. biofilms. The ability to form biofilms also determines the pathogenicity of bacteria and is of great importance in the process of infection (Różalska, 2008; Trafny, 2008). In humans, a number of diseases, such as endocarditis, urinary tract infections, chronic otitis media, chronic bacterial prostatitis,

* Corresponding author: S. Parasion, Military Institute of Hygiene and Epidemiology, Biological Threat Identification and Countermeasure Centre, Lubelska 2, 24-100 Puławy, Poland; phone: 00488155198 14; e-mail: sparasion@gmail.com 
respiratory tract infections in cystic fibrosis patients, or periodontal infections have been clearly linked with the associated biofilm development (Costerton et al., 1999; Davey and O'Toole, 2000).

Microbes capable of forming structurally and metabolically ordered cellular aggregates can colonize biomaterials in direct contact with tissues or systemic fluids. Biomaterials are used to manufacture pacemakers and cardiac valves, urinary tract prostheses, articular prostheses, peritoneal membrane implants, some dialysis catheters and respirators. Etiological factors of infections associated with biomaterials may include microorganisms comprising the natural microflora of the skin, oral cavity, urinary and reproductive system, the gastrointestinal tract, as well as exogenous organisms. The most commonly isolated bacterial species include coagulase-negative staphylococci, Staphylococcus aureus, Enterococcus faecalis, Enterococcus faecium, Escherichia coli, Proteus mirabilis, Klebsiella pneumoniae, Pseudomonas aeruginosa and Acinetobacter spp. (Donlan and Costerton, 2002; Donlan, 2005; Trafny, 2008). Biofilms formed on various medical devices complicate the healing process and become a serious healthcare issue. Due to the significant increase in the number of antibiotic multiresistant bacterial strains, medical and scientific research is focused on alternative strategies to fight biofilm development. Bacteriophages are the bacteria's natural enemies; therefore, they may be one of the most appealing solutions to this problem (Sutherland et al., 2004; Azeredo and Sutherland, 2008; Donlan, 2009).

\section{Bacteriophages - their prevalence, classification and life cycle}

Bacterial viruses were discovered independently about 100 years ago by Ernest Hankin (1896) and Frederick Twort (1915) - they were the first scientists to describe their antibacterial activity. However, it was a French Canadian microbiologist Felix d'Hérelle (1916) who suggested, that these entities were viruses. He gave them the name of bacteriophages and is officially credited with their discovery. D'Hérelle isolated bacteriophages for bacteria responsible for such diseases as cholera, bubonic plague or anthrax and was the first to use phage therapy in the treatment of bacterial dysentery. The first antibiotic - penicillin - was first used twenty years after the official discovery of bacteriophages. This fact, combined with some early clinical failures as well as theoretical and ethical concerns (foreign DNA) led to renouncement of phage therapy in the US and in most Western European Countries.

Bacteriophages are probably the most numerous and most diverse group of viruses. According to one of the hypotheses, at least one phage can be found for each host wherever bacterial development is observed. Soil, water, sewage, human and animal organisms (skin, mouth, saliva, stool, bowels), and even the food we eat are only some examples of environments from which phages have been isolated (Furuse, 1987; Ashelford et al., 2003). The estimated global population of phages is enormously large. It is estimated that the total number of phages in the aquatic environment is above $10^{31}$, land ecosystems demonstrate $10^{7}$ phage particles per 1 gram of soil, and the total number of phages in sewage is $10^{8}-10^{10}$ per $1 \mathrm{~mL}$. Phages were demonstrated to outnumber bacteria in all tested environments and may constitute the most dominant form of life in the biosphere (Sharp, 2001; Ashelford et al., 2003).

The taxonomic division of bacteriophages was established by the International Committee on the Taxonomy of Viruses (ICTV) on the basis of the morphology of the nucleic acid (dsDNA, ssDNA, dsRNA, ssRNA) (Rohwer and Edwards, 2002; Ackermann, 2006).

Each phage particle consists of nucleic acid (genetic material) and proteins that comprise the main structural elements of phages and exhibit enzymatic activity. There are filamentous phages, isosahedral phages with tails, phages without tails, and several phages with a lipoprotein envelope or contain lipids in the particle shell (Ackermann, 2006). Like all viruses, bacteriophages can proliferate only in living and susceptible bacterial cells. Phages can be divided into two types, depending on the course of infection: virulent, or lytic phages, and temperate, or lysogenic phages. Only lytic phages qualify for therapeutic purposes, as they lead to lysis of the host cell and do not integrate with the host genome ( Matsuzaki et al., 2005).

During the lytic cycle, phage particles are adsorbed on the bacterial surface; next, the genetic material of the phage permeates into the cell and takes over the host cell metabolism. This leads to a multiplication of offspring phages, cell lysis and the release of new phages into the environment. The first stage of the lytic cycle, i.e. adsorption, is facilitated by viral tail filaments that bind specific receptors on the surface of the cell. Phage receptors may include lipopolysaccharides (LPSs), corresponding proteins, sugar molecules and fimbriae. The specificity of the receptors determines the range of phage host organisms. It is worth mentioning that phages can be divided into monovalent phages, i.e. capable of adsorb to specific bacterial species or to specific strains, and polyvalent phages, able to infect across bacterial species or genera. During the lysogenic cycle, the viral genome integrates into the host's replicon and remains as a prophage within the bacterium. This prophage will remain as the lysogen until induction takes place, triggering a shift to the lytic cycle and 
the production of new phages in the system (Matsuzaki et al., 2005; Clark and March, 2006).

\section{Phages in therapy}

The discovery of phages as bacteria-eliminating factors suggested their possible therapeutic uses. Due to their nature, bacteriophages have many advantages as therapeutic agents. First of all, they are highly specific and efficient against their target bacteria; therefore, in contrast to most antibiotics, they do not cause a reduction or even elimination of natural microflora in host organisms. Phages do not infect human or animal cells, and various administration methods are available; phages replicate in susceptible bacteria as long as they are available (Clark and March, 2006; Skurnik and Strauch, 2006). The mechanism of the action of bacteriophages is different from that of antibiotics, which makes them effective against multiresistant bacteria. In addition, the selection process of phage-resistant bacteria is ten times slower than in case of antibioticresistant bacteria (Hanlon, 2007). It should be also mentioned that phage production is easy, fast and relatively unexpensive.

Phages have been and continue to be used to treat infectious diseases in plants (Fox, 2000) and animals (Barrow et al., 1998). Phage therapy has been used in humans in the treatment of such diseases as dysentery, skin infections, pulmonary infections, meningitis, infected wounds or myelitis, caused by numerous diverse organisms, including Staphylococcus spp., Streptococcus spp., E. coli, P. aeruginosa, Shigella spp. and Salmonella spp. A high level of efficacy of phage therapy was observed in murine infections with vancomycinresistant Enterococcus faecium (VRE). A single injection of $3 \times 10^{8} \mathrm{pfu}$ (plaque forming units) of an active phage 45 minutes after administration of $10^{9} \mathrm{cfu}$ (colony forming units) of VRE was sufficient for the eradication of the pathogen and resolution of clinical symptoms in $100 \%$ of tested mice. Even when the phage was administered late, under critical clinical conditions, $c a .50 \%$ of mice fully recovered (Biswas et al., 2002). Attention is drawn to the possibility of using phages in urinary tract infections. Preliminary clinical trials in patients infected with E. coli, Pseudomonas spp., Klebsiella spp., Enterobacter spp. and S. aureus suggest a high level of efficacy of phages following oral administration (Dzuliashvili et al., 2007). The spread of multidrug-resistant P. aeruginosa infections persuaded researchers to carry out preclinical studies with phage preparations (virulent bacteriophage clone cocktails). The in vitro activity of such cocktails was observed for $99.5 \%$ out of 206 tested species, and the therapeutic efficacy in studies conducted in white mice was in the range of $80-100 \%$ and was higher than that of ciprofloxacin (50-80\%).
A combination of antibiotic and phage ensured 100\% therapeutic efficacy (Dzuliashvili et al., 2007). The use of phages in mice with burn wounds additionally infected by subcutaneous injection of $P$. aeruginosa also produced good therapeutic results, largely dependent on the method of administration of the phage. The most effective route of administration (87\%) in generalized infection was intraperitoneal injection; intramuscular and subcutaneous administration were less effective - 28 and 22\%, respectively (McVay et al., 2007).

Most cases employing phage therapy in humans were not subject to the strict supervision typical for clinical trials. However, positive treatment results and lack of adverse effects have stimulated an increasing interest in this type of therapy and research in bacteriophage biology (Sulakvelidze et al., 2001; Tenover, 2001). The George Eliava Institute of Bacteriophage, Microbiology and Virology in Tbilisi (Georgia) can boast significant achievements in phage therapy. In their greatest period, the Institute employed about 1,200 workers and produced several tons of phage preparations per day. Also in Poland, the Institute of Immunology and Experimental Therapy of the Polish Academy of Sciences in Wrocław has been active in phage therapy applications since 1957. The use of phages in the treatment of various infections may reduce the use of antibiotics, and thus reduce the spread of multidrug-resistant bacteria.

Phage therapy is associated with some problems, mostly regarding the introduction of foreign genetic material into the patient's system, with the possibility of transferring the undesirable traits of gene encoding. Therefore, researchers focus their attention on phage enzymes that take part in degradation of bacterial walls and shells. These are lytic enzymes that hydrolyze peptidoglycans in both the carbohydrate and protein part of the molecule; this enzymes in the case of Gram-plus bacteria are active both outside (environment), and inside the host cells (Brzozowska et al., 2011). The in vivo efficacy of lysines was confirmed for Streptococcus pyogens (Nelson et al., 2001), Bacillus anthracis (Schuch et al., 2002) and antibiotic-resistant S. aureus strains (O’Flaherty et al., 2005).

\section{Bacteriophage-biofilm interactions}

Numerous phages have been used to fight bacterial biofilms; however, phage-biofilm interactions are relatively complex and very diverse. Bacteriophages may infect biofilm-forming bacteria as well as planktonic bacteria passing into the biofilm upon formation; phages may be trapped non-specifically in the biofilm EPS, as well as produce enzymes that disturb the stability of this extracellular polymer. Biofilm may also show a resistance to phage infection (Sutherland et al., 2004). 
In theory, biofilm should become infected faster than planktonic cells, as the vicinity of the cells in the biofilm structure may increase the phage replication rate (Hanlon, 2007). On the other hand, the structure and composition of the biofilm, as well as the physiology of biofilm cells, may impose some limitations in this regard. Various imaging techniques, including confocal microscopy with fluorescent in situ hybridization (FISH) and atomic force microscopy have revealed the heterogeneity of biofilm structures with a diverse distribution of cells, matrix, and water-filled channels and pores. It is worth mentioning that many biofilms have open structures with water-filled channels that facilitate phage access inside the biofilm (Sutherland et al., 2004; Donlan, 2009; Dollittle et al., 1996) demonstrated the radial movement of $\mathrm{T} 4$ phage molecule across the biofilm, similar to the process of forming clear patches in the bacterial lawn, suggesting that biofilms may be destroyed by single phage doses. In addition, Lactococcus phage c2 has been observed to have the ability to penetrate the biofilm through water channels and cell clusters. Similar phenomenon has also been observed in case of the biofilm of Stenotrophomonas maltophila, the cells of which were not sensitive to this phage (Briandet et al., 2008).

Besides the fact that phages are capable of reducing the number of bacterial cells in biofilms, there are several factors that may lead to a reduction in the lytic efficacy of phages (temperature, medium composition, EPS matrix type, etc.), resulting in a less effective phage action on the target cells. Also the metabolic status of bacterial cells in biofilms may pose problems for phage treatment, as cells in exponential growth are attacked faster that cells at later phases of growth. However, in some cases, the diversity of the biofilm structure, a deficiency of nutrients and a slow bacterial metabolism are no obstacles for the lytic phage cycle. Hadas et al. (1997) demonstrated that the burst size of T4 phages, i.e. the number of phages released following their replication was in the range of 12 to $200 \mathrm{pfu}$, depending on the physiological condition of the host cell (E. coli). In addition, the bacteriophage $\mathrm{T} 4$ remained capable of infecting bacterial cells even with a limited availability of nutrients. An increase in the amount of nutrients caused an increase in bacterial cell growth, leading to larger burst sizes and a reduction of eclipse and latency periods. Further studies showed that the age of P. aeruginosa biofilm only marginally reduced its susceptibility to phage activity F116 (Hanlon et al., 2001). The bacteriophage was active even against biofilms that were 20 days old. For many phages biofilm matrix is a barrier preventing from the phage infection. Doolittle et al. (1996), have reported that a P. aeruginosa phage was unable to reach the host cells in the deeper layers of a biofilm suggesting that the phage could not penetrate through the biofilm matrix. Additionaly, the biofilm matrix is also a reservoir of proteolytic enzymes which can lead to bacteriophage inactivation.

The first and most fundamental step in bacteriophage infection is the adsorption of phage particles to the specific receptors on the surface of the bacterial cell. In biofilms, where bacterial microcolonies are surrounded by EPS, the matrix is the factor that may pose a problem for phages in reaching their receptors on the target cell surface. However, it has been observed that some phages are able to overcome this obstacle and penetrate the extracellular matrix due to their "accompanying" enzymes. These enzymes hydrolyze the EPS so that bacteriophages can reach the lipopolysaccharide, external membrane proteins or other receptors crucial for the initiation of productive phage infection (Hughes etal., 1998a; Hughes et al., 1998b; Donlan, 2009). Numerous phages that induce enzymes capable of degrading the EPS in many Gram-negative bacteria, including bacteria capable of biofilm formation, have been isolated. On culture plates, such phages are characterized by halos of different sizes, surrounding the plaques obtained after the infection of a single bacterial cell. The halos are formed by bacteria from which the EPS has been removed by excess phage enzyme released during the lysis of infected cells (Sutherland etal., 2004). The activity of polysaccharide depolymerases was observed in the case of phage SF153b acting against Enterobacter agglomerans biofilms (Hughes etal., 1998b). Moreover, Hanlon demonstrated the diffusion of the anti-P. aeruginosa phage across the alginate gel structure, as well as showing that the mixture of pure, phage-free depolymerases reduces the viscosity of the alginate and EPS in P. aeruginosa (Hanlon et al., 2001). Another example of enzyme associated with bacteriophages infecting cystic fibrosis strains of P. aeruginosa, able to degrade extracellular alginic acids was described by Glonti and co-workers in 2010 (Glonti et al., 2010). Microscopic analysis of the halo zones formed on $P$. putida lawns by recombinantly purified tail spikes bacteriophage $\varphi 15$, which possesses EPS degrading activity, clearly shows that most of bacteria within the halo zones were separated from each other, their EPS material was reduced or completely removed (Cornelissen et al., 2011). A small single dose of endosialidase E, which degrades $N$-acetylneuraminic acid capsule, has therapeutic utility in systemic infections due to E. coli $\mathrm{K} 1$ strains in neonatal rats (Mushtaq et al., 2005). However, these enzymes are highly specific and rarely effective against more than a few types of polysaccharides.

Depolymerase synthesis in some phages is very useful for biofilm destruction. However, this is not a common trait; therefore, e.g. the T7 phage was modified to by genetic engineering methods to include genes that led to the production of EPS-degrading enzymes 
(Azeredo and Sutherland, 2008, Donlan, 2009). Unfortunately, this genetic modification led to a reduced antibiofilm activity compared to the native phage (Lu and Collins, 2007).

\section{The use of bacteriophages to fight biofilms}

In recent years, bacteriophages have been more and more frequently used in the treatment of infections in humans and animals; however, studies involving bacteriophages have usually been carried out in standard laboratory cultures, i.e. in planktonic cells, not in biofilm-forming cells. The first experiments involving the use of phages in fighting biofilms were published as recently as 1995. Many experiments using various bacteriophages and various bacterial biofilms have been conducted to date (Table I), suggesting that phages are capable of reducing the bacterial population in this particular form of bacterial cultivation.

Two strategies have been identified for the use of bacteriophages in fighting biofilms - prevention, i.e. blocking the onset of biofilm development, and eradication, i.e. removal of an existing biofilm (Azeredo and Sutherland, 2008; Donlan, 2009; Różalska et al., 2010).

Himba et al. (1997) were the first authors to document the use of phages to prevent the development of Listeria monocytogenes biofilms on a stainless steel surface. A very important research project on preventing the adhesion and proliferation of bacteria on the surfaces of medical devices was carried out in 2006 by Curtin and Donlan. It was demonstrated that the phage active against Staphylococcus epidermidis, introduced into the hydrogel coating of a catheter significantly reduced the formation of the biofilm of this microorganism in vitro. Fu et al. (2010) made use of a similar in vitro model to verify whether phage pre-treatment might reduce the formation of P. aeruginosa biofilms. To this end, three experimental approaches were used - phage lysate was passed through the catheters before, immediately after and $24 \mathrm{~h}$ after exposure to P. aeruginosa. The experiment was conducted in two series. In the first series, a single M4 phage lysate was used, while the second series made use of a phage cocktail consisting of M4 and four other phages selected according to the sensitivity profile of the bacteria comprising the biofilm formed at the first stage of the experiment. It was shown that the treatment of catheters with M4 phage before bacterial exposure significantly reduced bacterial adhesion to the catheter surfaces, and thus biofilm formation $(<99 \%)$. The biofilm that formed after a period of time was easily eradicated by the phage cocktail, which was more effective than the single phage due to a wider scope of activity and a lower possibility of developing phage resistance by the biofilm bacteria
(Fu et al., 2010). These results confirm the legitimacy of using phages to protect medical devices from the formation of biofilms by clinical strains of bacteria.

Of particular note is the potential use of bacteriophages to prevent the formation of biofilms on the surfaces of catheters and other medical biomaterials, although many issues, such as phage infectability and stability, the ability of a particular material to adsorb phage and phage stability in the presence of plasma proteins, require further studies. In addition, careful selection of phage cocktails, matrix optimization and validation of methods in vitro and in animal models are very important in the assessment of the usefulness of bacteriophages in fighting biofilms (Donlan, 2009).

Another strategy consists in using lytic bacteriophages to eradicate already formed biofilms. Every year, more and more information is published regarding the biofilm eradication capability of bacteriophages (Table I). Studies showed that some of the most important obstacles that disqualify antibiotics from being used in biofilm treatment, such as the development of tolerance (lack of bactericidal effect), the presence of EPS and the effect of biofilm age, may be overcome by bacteriophages (Sutherland et al., 2004; Donlan, 2009). When a phage makes contact with the biofilm, further interactions depend on the susceptibility of the biofilm-forming bacteria and the availability of receptors on the cell surface. If the bacteriophages are equipped with enzymes that degrade polysaccharides, or if a significant number of cells undergo lysis, the integrity of the biofilm may be broken. Phages producing large amounts of depolimerases, as mentioned in the previous section, are important for eradicating biofilms. Such activity leads to a disturbance of the EPS structural stability and thus to bacteriophage access and adsorption to target cells followed by the infection and lysis of biofilm-forming cells (Hughes et al., 1998a).

Several phages that were used in biofilm eradication have been defined. E. coli biofilm was found to be sensitive to bacteriophage T4 (Doolittle et al., 1995). Sharma et al. (2005) described the synergistic effect of a commercial alkaline cleanser (Enforce ${ }^{\oplus}$-Ecolab, Inc., St Paul, $\mathrm{MN}, \mathrm{USA}$ ) and bacteriophage $\mathrm{KH} 1$ in the deactivation of biofilm formed by E. coli O157:H7 on a stainless steel surface. Sillankorva et al. (2004) demonstrated the efficacy of phages in the eradication of P.fluorescens biofilm at both early and advanced (5 days) stages of development. A combination of antibiotic therapy with therapeutic phage activity was also found to be more efficient in the removal of $K$. pneumoniae biofilm (Bedi et al., 2009).

As shown in numerous experiments, phages may effectively infect bacteria and cause bacterial lysis in single-species biofilms (Hughes et al., 1998b, Hanlon et al., 2001; Tait et al., 2002; Sillankorva et al., 2004; 
Table I

List of experiments illustrating the effects of phages on bacterial biofilms

\begin{tabular}{|c|c|c|c|}
\hline $\begin{array}{l}\text { Biofilm forming } \\
\text { bacteria }\end{array}$ & Phages & Year & Experimental results and reference \\
\hline E. coli & $\mathrm{T} 4$ & 1995 & $\begin{array}{l}\text { - eradication of existing biofilm, } 28 \mathrm{~h} \text { biofilms treated with } 10^{9} \text { or } 10^{10} \mathrm{PFU} / \mathrm{ml} \\
\text { phage for } 30 \mathrm{~min} \text { to } 8 \mathrm{~h} \text { [Doolite et al.] }\end{array}$ \\
\hline E. coli, P. aeruginosa & T4, E79 & 1996 & $\begin{array}{l}\text { - eradication of existing biofilm, phage T4 infected both surface-attached } \\
\text { and surface-associated E. coli, phage E79 adsorbed only to } \text { P. aeruginosa cells } \\
\text { on the surface of the biofilm [Doolite } \text { et al.] }\end{array}$ \\
\hline L. monocytogenes & 2307-B1 & 1997 & $\begin{array}{l}\text { - eradication of existing biofilm, passive treatment }\left(10^{10} \text { phages } / \mathrm{ml}\right) \text { was used, } \\
\left.3 \log _{10} \text { reduction in biofilm viable count within } 6 \mathrm{~h} \text { [Himba et al. }\right]\end{array}$ \\
\hline E. agglomerans $53 \mathrm{~b}$ & SF153b & 1998 & $\begin{array}{l}\text { - eradication of existing biofilm, EPS degradation, } 24 \mathrm{~h} \text { biofilms treated } \\
\text { with } 10^{10} \mathrm{PFU} / \mathrm{ml} \text { of phage for } 15 \mathrm{~min} \text { [Hughes et al. b] }\end{array}$ \\
\hline E. coli $\mathrm{K}-12$ & $\mathrm{~T} 4$ & \multirow[t]{3}{*}{2001} & $\begin{array}{l}\text { - eradication of existing biofilm, small phage impact, bacterial density after } \\
3 \text { hours was reduced about } 1,5 \log _{10} \text { [Corbin et al.] }\end{array}$ \\
\hline P. aeruginosa & F116 & & $\begin{array}{l}\text { - eradication of existing biofilm, 2-log reduction in the cell, numbers } \\
\text { in } 20 \text {-day-old biofilms, time- and concentration-dependent reduction } \\
\text { in alginate viscosity of up to } 40 \% \text { [Hanlon } \text { et al.] }\end{array}$ \\
\hline S. epidermidis & ?phage & & - eradication of existing biofilm, in vitro catherer model [Wood et al.] \\
\hline $\begin{array}{l}\text { E. cloace, } \\
\text { E. agglomerans }\end{array}$ & $\begin{array}{l}\text { 11229, } \varphi \text { Ent, } \varphi 1.15 \\
\text { Blackburn, Philipstown }\end{array}$ & 2002 & $\begin{array}{l}\text { - eradication of existing dual-species biofilm, treatment of purified EPS } \\
\text { depolymerase and various chemical disinfectants [Tait et al.] }\end{array}$ \\
\hline P. fluorescens & $\varphi S 1$ & 2004 & $\begin{array}{l}\text { - eradication of existing biofilm, } 5 \text { day biofilms treated with } 10^{9} \mathrm{PFU} / \mathrm{ml} \\
\text { phage at different temperatures, approximately one-log reduction } \\
(85 \% \text { after } 200 \mathrm{~min}) \text { [Sillankorva } \text { et al.] }\end{array}$ \\
\hline E. coli $\mathrm{O} 157$ & KH1 & 2005 & $\begin{array}{l}\text { - eradication of existing biofilm, phages as well as various cleanser } \\
\text { and disinfectants solutions to kill E. coli found in biofilms adhering } \\
\text { to stainless steel surface [Sharma et al.] }\end{array}$ \\
\hline S. epidermidis & 456 & \multirow[t]{2}{*}{2006} & $\begin{array}{l}\text { - prevention of biofilm formation, pre-treatment of catheter surfaces } \\
\text { with phages [Curtin and Donlan] }\end{array}$ \\
\hline S. aureus & $\varphi 11, \varphi 12$ & & $\begin{array}{l}\text { - determination of influence of the } \varphi 11 \text { and } \varphi 12 \text { endolysins on staphylococcal } \\
\text { biofilms by a modified biofilm plate assay [Sass and Bierbaum] }\end{array}$ \\
\hline S. epidermidis & $\mathrm{K}$ & \multirow[t]{2}{*}{2007} & $\begin{array}{l}\text { - eradication of existing biofilm, passive treatment with } 2 \times 10^{8} \text { of phage } \mathrm{K} \text {, } \\
\text { one log biofilm reduction after } 24 \mathrm{~h} \text { [Cerca et al.] }\end{array}$ \\
\hline E. coli TG1 & $\mathrm{T} 7$ & & $\begin{array}{l}\text { - engineered phage substantially reduced bacterial biofilm cell counts } \\
\text { by } 4.5 \text { orders of magnitude ( } 99.997 \% \text { removal) [Lu and Collins] }\end{array}$ \\
\hline S. maltophilia & $\mathrm{C} 2$ & \multirow[t]{2}{*}{2008} & $\begin{array}{l}\text { - studies diffusion and reaction of phages in biofilms; biofilms did not confer } \\
\text { resistance to the entrapment of virus-size particles and to their diffusion } \\
\text { [Briandet } \text { et al.] }\end{array}$ \\
\hline P. fluorescens & $\varphi S 1$ & & $\begin{array}{l}\text { - eradication of bacterial cells by phages at the early stage of biofilm formation } \\
\text { [Sillankorva et al.] }\end{array}$ \\
\hline $\begin{array}{l}\text { P. aeruginosa, } \\
\text { A. johnsonii, B. subtilis }\end{array}$ & Bacteria-specific phages & \multirow[t]{2}{*}{2009} & $\begin{array}{l}\text { - the first report revealing the potential of phage usage as an anti-biofouling } \\
\text { factor in membrane processes [Goldmann et al.] }\end{array}$ \\
\hline K.pneumonia B5055 & Phage + antibiotic & & $\begin{array}{l}\text { - eradication of biofilm, efficacy of bacteriophage alone or in combination } \\
\text { with amoxicillin, the combination therapy gives better results than } \\
\text { the two therapies alone [Bedi et al.] }\end{array}$ \\
\hline S. aureus & SAP-2 & \multirow[t]{4}{*}{2010} & $\begin{array}{l}\text { - biofilm removal activity of bacteriophage and a cell-wall-degrading } \\
\text { enzyme (SAL-2), derived from SAP-2; enzyme showed a broader spectrum } \\
\text { of activity [Son } \text { et al.] }\end{array}$ \\
\hline L. monocytogenes & P100 & & $\begin{array}{l}\text { - irrespective of the serotype, growth conditions, or biofilm levels, phage } \\
\text { significantly reduced L. monocytogenes biofilm [Soni and Nannapaneni] }\end{array}$ \\
\hline P. fluorescens, S. lentus & IBB-PF7A, IBB-SL58B & & $\begin{array}{l}\text { - studies mono and dual species biofilms formed by P. fluorescens } \\
\text { and/or S. lentus, cocktail of phages effectively killed and removed the hosts } \\
\text { from the biofilm [Sillankorva et al.] }\end{array}$ \\
\hline P. aeruginosa & M4 & & $\begin{array}{l}\text { - pretreating hydrogel-coated catheters with } P \text {. aeruginosa bacteriophages } \\
\text { cocktail on biofilm formation, reduction viable biofilm count about } \\
2.8 \log _{10} \text { CFU cm } \text { cm }^{2} \text { et al.] }\end{array}$ \\
\hline
\end{tabular}


Table I cnontinued

\begin{tabular}{|c|c|c|c|}
\hline $\begin{array}{l}\text { Biofilm forming } \\
\text { bacteria }\end{array}$ & Phages & Year & Experimental results and reference \\
\hline P. aeruginosa & $\begin{array}{l}\text { phiIBB-PAP21, } \\
\text { phiIBB-PAA2 }\end{array}$ & \multirow[t]{4}{*}{2011} & $\begin{array}{l}\text { - control of both planktonic cultures and biofilms, biofilm cells of } P \text {. aeruginosa } \\
\text { PAO1 acquired resistance to phiIBB-PAP21, phage phiIB-PAA2 continued } \\
\text { to destroy biofilm cells, even after } 24 \mathrm{~h} \text { of infection [Pires et al.] }\end{array}$ \\
\hline P. aeruginosa & $\mathrm{BVPaP}-3$ & & $\begin{array}{l}\text { - control of biofilm, phage at MOI- } 0.001 \text { could prevent biofilm formation } \\
\text { by P. aeruginosa hospital strain on the pegs within } 24 \mathrm{~h} \text { [Ahiwale } \text { et al.] }\end{array}$ \\
\hline E. coli, $P$. aeruginosa & $\lambda \mathrm{W} 60, \mathrm{~PB}-1$ & & $\begin{array}{l}\text { - examination of phage infection on the viability of monoculture and mixed } \\
\text { species biofilm and planktonic cultures [Kay et al.] }\end{array}$ \\
\hline C. jejuni & CP8, CP30 & & $\begin{array}{l}\text { - control of biofilm, phages within the biofilm could not only effectively } \\
\text { target and lyse cell but were also able to disperse the EPS forming } \\
\text { the biofilm [Siringan } \text { et al.] }\end{array}$ \\
\hline
\end{tabular}

Sharma et al., 2005; Lu and Collins, 2007). However, in many cases the problem is caused by a multispecies biofilm, where phage-biofilm interactions may be more complex (Sutherland et al., 2004; Azeredo and Sutherland, 2008). An attempt to eradicate a biofilm caused by two bacterial species of genus Enterobacter by phages and polysaccharide depolymerases failed to achieve the goal (Tait et al., 2002). Recent studies by Sillankorva et al. (2010) referred to a case where a biofilm formed by two bacterial species (S. lentus and P. fluorescens), was successfully subjected to the action of lytic phages - a polyvalent Staphylococcus phage and Pseudomonas phage known from earlier studies (IBB-PF7A). The authors underlined the importance of the optimization of conditions in which bacteriophages are used to eradicate biofilms. The studies showed that both single- and dual-species biofilms may be effectively controlled by phages; the phages may effectively reach relevant susceptible host cells and cause the lysis of these cells. Further research on simultaneous use of phages and other antimicrobial agents also seems justified (Sillankorva et al., 2010).

\section{Summary}

The development of new methods of fighting biofilms is currently one of the major problems in medicine. Numerous in vitro experiments have shown that phages can infect bacterial cells within biofilms, and the depolymerases of some phages facilitate the penetration of phages into the inner layers of the biofilm by means of EPS degradation. This leads to the conclusion that the use of bacteriophages might become a new strategy in the prevention and eradication of biofilms. In addition, genetic modifications of phages might bring about a higher efficacy against biofilms, and the use of various phage mix compositions would prevent or minimize phage resistance. However, before bacteriophages can be used to fight biofilms, procedures for the development of phage preparations, as well as procedures for phage administration and dosage regimens must be established to guarantee the efficacy and safety of such treatment.

\section{References}

Ackermann H.W. 2006. Classification of bacteriophages. The Bacteriophages, Ed. Calendar R, Oxford University Press, ISBN 0-19514850-9, New York, USA, pp. 8-16

Ahiwale S., N. Tamboli, K. Thorat, R. Kulkarni, H.W. Ackermann and B. Kapadnis. 2011. In vitro management of hospital Pseudomonas aeruginosa biofilm using indigenous T7-like lytic phage. Curr. Microbiol. 62: 335-340.

Ashelford K.E., M.J. Day and J.C. Fry. 2003. Elevated abundance of bacteriophage infecting bacteria in soil. Appl. Environ. Microbiol. 69: 285-289.

Azeredo J. and I.W. Sutherland. 2008. The use of phages for the removal of infectious biofilms. Curr. Pharm. Biotechnol. 9: 261-266. Barrow P., M. Lovell and A.Jr. Berchieri. 1998. Use of lytic bacteriophage for control of experimental Escherichia coli septicemia and meningitis in chickens and calves. Clin. Diagn. Lab. Immunol. 5: 294-298.

Bedi M.S., V. Verma and S. Chibber. 2009. Amoxicillin and specific bacteriophage can be used together for eradication of biofilm of Klebsiella pneumoniae B5055. World J. Microbiol. Biotechnol. 25: 1145-1151.

Biswas B., S. Adhya, P. Washart, B. Paul, A.N. Trostel, B. Powell, R. Carlton and C.R. Merril. 2002. Bacteriophage therapy rescues mice bacteremic from a clinical isolate of vancomycin resistant Enterococcus faecium. Infect. Immun. 70: 204-210.

Briandet R., P. Lacroix-Gueu, M. Renault, S. Lecart, T. Meylheuc, E. Bidnenko, K. Steenkeste, M.-N. Bellon-Fontaine and M.-P. Fontaine-Aupart. 2008. Fluorescence correlation spectroscopy to study diffusion and reaction of bacteriophages inside biofilms. Appl. Environ. Microbiol. 74: 2135-2143.

Brzozowska E., J. Bazan and A. Gamian. 2011. Funkcje białek bakteriofagowych. Postepy Hig. Med. Dosw. 65: 167-176.

Cerca N., R. Oliveira and J. Azeredo. 2007. Susceptibility of Staphylococcus epidermidis planktonic cells and biofilms to the lytic action of staphylococcus bacteriophage K. Lett. Appl. Microbiol. 45: 313-317.

Clark J.R. and J.B. March. 2006. Bacteriophages and biotechnology: vaccines, gene therapy and antibacterials. Trends Biotechnol. 24: 212-218. 
Corbin B.D., R.J.C. McLean and G.M. Aron. 2001. Bacteriophage T4 multiplication in a glucose-limited Escherichia coli biofilm. Can. I. Microbiol. 47: 680-684.

Cornelissen A., Ceyssens P.J., T'Syen J., Van Praet H., Noben J.P., Shaburova O.V., Krylov V.N., Volckaert G. and Lavigne R. 2011. The T7-Related Pseudomonas putida Phage $\$ 15$ Displays VirionAssociated Biofilm Degradation Properties. PLoS One 6: e18597. doi: 10.1371/journal.pone.0018597

Costerton J.W. 2007. The biofilm primer. Berlin Heidelberg, Springer-Verlag.

Costerton J.W., P.S. Stewart and E.P. Greenberg. 1999. Bacterial biofilms: a common cause of persistent infections. Science 284: $1318-1322$.

Curtin J.J. and R.M. Donlan. 2006. Using bacteriophages to reduce formation of catheter associated biofilms by Staphylococcus epidermidis. Antimicrob. Agents Chemother. 50: 1268-1275.

Dąbrowska K., K. Świtala-Jeleń, A. Opolski, B. Weber-Dąbrowska and A. Górski. 2005. Bacteriophage penetration in vertebrates. J. Appl. Microbiol. 98: 7-13.

Davey M.E. and G.A. O’Toole. 2000. Microbial biofilms: from ecology to molecular genetics. Microbiol. Mol. Biol. Rev. 64: 847-867.

Donlan R.M. 2005. New approaches for the characterization of prosthetic joint biofilms. Clin. Orthop. Relat. Resl. 437: 12-19.

Donlan R.M. 2009. Preventing biofilms of clinically relevant organisms using bacteriophage. Trends Microbiol. 17: 66-72.

Donlan R.M. and J.W. Costerton. 2002. Biofilms: survival mechanisms of clinically relevant microorganisms. Clin. Microbiol. Rev. 15: 167-193.

Doolittle M.M., J.J. Cooney and D.E. Caldwell. 1995. Lytic infection of Escherichia coli biofilms by bacteriophage-T4. Can. J. Microbiol. 41: 12-18.

Doolittle M.M., J.J. Cooney and D.E. Caldwell. 1996. Tracing the interaction of bacteriophage with bacterial biofilms using fluorescent and chromogenic probes. J. Ind. Microbiol. 16: 331-341.

Dzuliashvili M., K. Gabitashvili, A. Golidjashvili, N. Hoyle and K. Gachechiladze. 2007. Study of therapeutic potential of the experimental pseudomonas bacteriophage preparation. Georgian Med. News 147: 81-8.

Fox J. 2000. Phage treatments yield healthier tomato, pepper plants. ASM News 66: 455-456.

Fu W., T. Forster, O. Mayer, J.J. Curtin, S.M. Lehman and R.M. Donlan. 2010. Bacteriophage cocktail for the prevention of biofilm formation by Pseudomonas aeruginosa on catheters in an in vitro model system. Antimicrob. Agents Chemother. 54: 397-404.

Furuse K. 1987. Distribution of coliphages in the general environment: general considerations. In: Phage ecology, pp. 87-124. New York, N.Y.: John Wiley \& Sons.

Glonti T., N. Chanishvili and P.W. Taylor. 2010. Bacteriophagederived enzyme that depolymerizes the alginic acid capsule associated with cystic fibrosis isolates of Pseudomonas aeruginosa. J. Appl. Microbiol. 108: 695-702.

Goldman G., J. Starosvetskyand and R. Armon. 2009. Inhibition of biofilm formation on UF membrane by use of specific bacteriophages. J. Memb. Sci. 342: 145-152.

Hadas H., M. Einav, I. Fishov and A. Zaritsky. 1997. Bacteriophage T4 development depends on the physiology of its host Escherichia coli. Microbiology 143: 179-185.

Hanlon G.W. 2007. Bacteriophages: an appraisal of their role in the treatment of bacterial infections. Int. J. Antimicrob. Agents 30: 118-128.

Hanlon G.W., S.P. Denyer, C.J. Olliff and L.J. Ibrahim. 2001. Reduction of exopolysaccharide viscosity as an aid to bacteriophage penetration through Pseudomonas aeruginosa biofilms. Appl. Environ. Microbiol. 67: 2746-2753.
Hibma A.M., S.A. Jassim and M.W. Griffiths. 1997. Infection and removal of L-forms of Listeria monocytogenes with bred bacteriophage. Int. J. Food Microbiol. 34: 197-207.

Hughes K.A, I.W. Sutherland, J. Clark and M.V. Jones. 1998a. Bacteriophage and associated polysaccharide depolymerases - novel tools for study of bacterial biofilms. J. Appl. Microbiol. 85: 583-590. Hughes K.A., I.W. Sutherland, J. Clark and M.V. Jones. 1998b. Biofilm susceptibility to bacteriophage attack: the role of phageborne polysaccharide depolymerase. Microbiology 144: 3039-3047. Kay M.K., T.C. Erwin, R.J. McLean and G.M. Aron. 2011. Bacteriophage ecology in Escherichia coli and Pseudomonas aeruginosa mixed-biofilm communities. Appl. Environ. Microbiol. 77: 821-829. Lu T.K. and J.J. Collins. 2007. Dispersing biofilms with engineered enzymatic bacteriophage. Proc. Natl. Acad. Sci. USA 104: 11197-11202.

Matsuzaki S., M. Rashel, J. Uchiyama, S. Sakurai, T. Ujihara, M. Kuroda, M. Ikeuchi, T. Tani, M. Fujieda, H. Wakiguchi and S. Imai. 2005. Bacteriophage therapy: a revitalized therapy against bacterial infectious diseases. J. Infect. Chemother. 11:211-219.

McVay C.S., M. Velásquez and J.A. Fralick. 2007. Phage therapy of Pseudomonas aeruginosa infection in a mouse burn wound model. Antimicrob. Agents Chemother. 51: 1934-1938.

Mushtaq N., M.B. Redpath, J.P. Luzio and P.W. Taylor. 2005. Treatment of experimental Escherichia coli infection with recombinant bacteriophage-derived capsule depolymerase. J. Antimicrob. Chemother. 56:160-165.

Nelson D., L. Loomis and V.A. Fischetti. 2001. Prevention and elimination of upper respiratory colonization of mice by group A streptococci by using a bacteriophage lytic enzyme. Proc. Natl. Acad. Sci. USA 98: 4107-4112.

O'Flaherty S., A. Coffey, W. Meaney, G.F. Fitzgerald and R.P. Ross. 2005. The recombinant phage lysin LysK has a broad spectrum of lytic activity against clinically relevant staphylococci, including methicillin-resistant Staphylococcus aureus. J. Bacteriol. 187: 7161-7164.

Pires D., S. Sillankorva, A. Faustino and J. Azeredo. 2011. Use of newly isolated phages for control of Pseudomonas aeruginosa PAO1 and ATCC 10145 biofilms. Res. Microbiol. 162: 798-806.

Rohwer F. and R. Edwards. 2002. The Phage Proteomic Tree: a genome-based taxonomy for phage. J. Bacteriol. 184: 4529-4535.

Różalska B. 2008. Biofilmy drobnoustrojów i ich rola w zakażeniach. Sepsis 1: 49- 53.

Różalska B., E. Walecka and B. Sadowska. 2010. Wykrywanie biofilmów stanowiących problemy medyczne i perspektywy ich eradykacji. Zakażenia 10: 13-21.

Sass P. and G. Bierbaum. 2006. Lytic activity of recombinant bacteriophage phi11 and phi12 endolysins on whole cells and biofilms of Staphylococcus aureus. Appl. Environ. Microbiol. 73: 347-352.

Schuch R., D. Nelson and V.A. Fischetti. 2002. A bacteriolytic agent that detects and kills Bacillus anthracis. Nature 418: 884-889.

Sharma M., J.H. Ryu and L.R. Beuchat. 2005. Inactivation of Escherichia coli $\mathrm{O} 157: \mathrm{H7}$ in biofilm on stainless steel by treatment with an alkaline cleaner and a bacteriophage. J. App.l Microbiol. 99: 449-459. Sharp R. 2001. Bacteriophages: biology and history. J. Chem. Technol. Biotechnol. 76: 667-672.

Sillankorva S., P. Neubauer and J. Azeredo. 2010. Phage control of dual species biofilms of Pseudomonas fluorescens and Staphylococcus lentus. Biofouling 26: 567-575.

Sillankorva S., R. Oliveira, M.J. Vieira and J. Azeredo. 2008 Real-time quantification of Pseudomonas fluorescens cell removal from glass surfaces due to bacteriophage phiS1 application. J. Appl. Microbiol. 105: 196-202.

Sillankorva S., R. Oliveira, M.J. Vieira, I.W. Sutherland and J. Azeredo. 2004. Bacteriophage phiS1 infection of Pseudomonas fluorescens planktonic cells versus biofilms. Biofouling 20: 133-138. 
Siringan P., P.L. Connerton, R.J. Payne and I.F. Connerton. 2011 Bacteriophage-mediated dispersal of Campylobacter jejuni biofilms. Appl. Environ. Microbiol. 77: 3320-3326.

Skurnik M. and E. Strauch. 2006. Phage therapy: facts and fiction. Int. J. Med. Microbiol. 296: 5-14.

Son, J.S., S.J. Lee, S.Y. Jun, S.J. Yoon, S.H. Kang, H.R. Paik, J.O. Kang and Y.J. Choi. 2010. Antibacterial and biofilm removal activity of a podoviridae Staphylococcus aureus bacteriophage SAP-2 and a derived recombinant cell-wall-degrading enzyme. Appl. Microbiol. Biotechnol. 86: 1439-1449.

Soni K.A. and R. Nannapaneni. 2010. Removal of Listeria monocytogenes biofilms with bacteriophage P100. J. Food Prot. 73, 1519-1524 Sulakvelidze A., Z. Alavidze and J.G. Jr. Morris. 2001. Bacteriophage Therapy. Antimicrob. Agents Chemother. 45: 649-659.
Sutherland I.W., K.A. Hughes, L.C. Skillman and K. Tait. 2004. The interaction of phage and biofilms. FEMS Microbiol. Lett. 232: 1-6. Tait K., L.C. Skillman and I.W. Sutherland. 2002. The efficacy of bacteriophage as a method of biofilm eradication. Biofouling 18: 305-311.

Tenover F.C. 2001. Development and spread of bacterial resistance to antimicrobial agents: an overview. Clin. Infect. Dis. 33: 108-115. Trafny E.A. 2008. Rola biofilmów w patogenezie zakażeń człowieka. Postępy Microbiol. 47: 353-357.

Wood H.L., S.R. Holden and R. Bayston. 2001. Susceptibility of Staphylococcus epidermidis biofilm in CSF shunts to bacteriophage attack. Eur. J. Pediatr. Surg. 11: 556-557.

Zobell C.E. 1943. The effect of solid surfaces upon bacterial activity. J. Bacteriol. 46: 39-56. 
